\title{
POLITICAL PARTIES AND THE 2005 ELECTIONS IN ZIMBABWE
}

\author{
By
Lloyd M Sachikonye
}

Professor LIoyd Michael Sachikonye is a Senior Research Fellow / Lecturer at the University of Zimbabwe, the Institute of Development Studies,

P O Box 880, Harare

Tel: +263(4) 333341/3; Fax: +263(4) 333345

e-mail: sachi@zol.co.zw

\begin{abstract}
Parties play a crucial role in elections for they reflect the configuration of political power in the contestation for state control. Political parties constitute an important medium for citizens' participation in the political process during and between elections. How have parties fared in the context of the Zimbabwe political situation, in particular during the 2005 elections? Although the 2005 elections were as tightly contested as those of 2000 and 2002, there was a remarkable difference between them. The environment during the campaign of 2005 was peaceful, compared with the political violence and mayhem that accompanied the 2000 and 2002 elections. A new element built into the framework of the election campaign was the SADC Principles and Guidelines Governing Democratic Elections, a framework with which $S A D C$ member states were enjoined to comply. Another significant factor was the Zimbabwe Government's strategy of restricting the number and variety of observer missions that would be allowed to witness the election. This paper will not attempt to assess the 2005 election process as a whole but will concentrate on the role of political parties in the contest. Significantly, a major difference from previous elections was the reduction in the number of parties that contested the elections.
\end{abstract}

\section{INTRODUCTION}

This paper discusses the configuration of political power among parties in Zimbabwe, focusing on the 2005 National Assembly elections. We aim to establish how the balance of power among parties in the context of the dominant-party syndrome played itself out in the electoral contest itself, with special focus on the Zimbabwe African National Union-Patriotic Front (Zanu-PF) and the main opposition party, the Movement for Democratic Change (MDC). To this end and given that, since 2000, Zanu-PF and the MDC have been the major protagonists in Zimbabwe's political arena, we review the platforms and performance of these 
two parties, notwithstanding the participation of Zanu-Ndonga and the Zimbabwe Youth Alliance (ZIYA) in the 2005 elections.

The discussion begins by highlighting the issue of the institutionalisation of parties before going on to provide brief sketches of the profiles and strategies of the main parties that contested the 2005 elections. Zimbabwe currently has a dominant-party system in which the ruling Zanu-PF continues to entrench and reproduce its political hegemony, even in the face of a fierce political challenge posed by the opposition MDC. The struggle for dominance is reflected in the range of campaign issues around which the election was fought, and the unresolved controversy over unequal access to resources for the campaigns. The paper also examines the primary election system as a key aspect of internal party democracy, and as a contributing factor to the phenomenon of independent candidates. The concluding section revisits the disputes that surrounded the announcement and the substance of the results themselves.

\section{Party Institutionalisation: Some Conceptual Issues}

Historically, parties have played a pivotal role in the founding and consolidation of systems of governance. Parties seek to aggregate diverse demands into coherent programmes and elections are primarily fought around these programmes. In multiparty systems, parties facilitate a peaceful transfer of government power from one party to another, or from one coalition to another. Parties are created to articulate and defend specific social interests.

In relation to this, the nurturing of political trust within the political class, that is, between parties, is essential to the building of democracy, and remains a major challenge particularly to younger nation-states (Hall 1992). This trust must be consolidated and shared in a process that has been termed 'institutionalisation of loyal opposition'. Such an opposition shares the broad national interests of the existing state and ruling party as well as subscribing to the political system, including the electoral 'rules of the game'.

Institutionalisation relates to a process by which an organisation or practice becomes established and widely known (Mainwaring 1998). The institutionalisation of a party system ensures that actors have clear and stable expectations about the contours and rules of party competition and behaviour. In general, party systems in developing countries tend to be less institutionalised than those in longestablished democracies, notwithstanding that parties in the latter also face new challenges, including the erosion of their membership base.

Institutionalised party systems enjoy considerable stability; patterns of party competition manifest regularity. A system in which parties regularly appear and disappear or become minor parties can be described as weakly institutionalised. Finally, in more institutionalised systems, party organisations matter; parties are not subordinated to the ambitions of a few leaders but possess an independent status and value of their own (Mainwaring 1998). In sum, while institutionalised 
party systems are conducive to stable political systems, where such systems are weakly institutionalised, the political system may be prone to instability.

In Southern Africa, parties are key instruments in encouraging and mobilising participation in the political process. The level of membership varies greatly within and between countries but it remains an important barometer of political participation. In general, party membership reached a climax at independence or liberation but has gradually declined since then. As central players during elections, parties advertise competing platforms and seek to convince potential voters that they are the most appropriate to govern a country. Not surprisingly, most citizens in the region associate parties with 'elections' and it is at election time that new parties are explicitly formed to contest the elections. The formation of 'election-time' parties is a general trend in the region, reflecting an 'opportunistic' or 'entrepreneurial' approach. However, even well established parties have a tendency to be 'dormant' between elections, only springing into activity towards the start of the next electoral contest. Thus, a certain amount of 'electoralism' appears to pervade the strategic thinking and outlook of both ruling and opposition parties, old and new.

These broad considerations apply in Zimbabwe. Zanu-PF and the MDC have undergone substantial institutionalisation but other parties - among them the ZanuNdonga, the Democratic Party (DP) and the National Alliance for Good Governance (NAGG) - although they may have existed for some years have been weakly institutionalised, as reflected in their sparse membership. Founded in 1963, ZanuPF has an historical record and a substantial membership base. The MDC, formed in 1999 on the back of a wave of widespread disillusionment with the governance record of Zanu-PF, quickly established a substantial membership base amongst the working and middle classes and the urban population.

\section{Party Profiles And Strategies}

More than other parties, the MDC and Zanu-PF have a national reach and presence. They were the only parties capable of fielding contestants in all 120 directly contested seats. Drawing on branches spread throughout the country and on both district and provincial structures, the two parties have ambitious programmes. As the more seasoned of the two, Zanu-PF is the result of a merger of Zanu-PF and the Patriotic Front-Zimbabwe African People's Union (PF-Zapu) in 1987. It is a nationalist organisation that operated as a liberation movement in the 1960s and 1970s. A governing party since independence, it enunciated its objectives as preserving and defending 'the national sovereignty and independence of Zimbabwe' and establishing 'a socialist society firmly based on our historical, cultural and social experience' (Zanu-PF 1999). It pledged to continue to 'participate in the world-wide struggle for the complete eradication of imperialism, colonialism and all forms of racism'. Although Zanu-PF has had 25 years to implement its aims, objectives and overall agenda, it has fallen short of doing so. A prolonged economic and social crisis from 2000 is one indicator of the party's shortcomings. 
In contrast, the MDC, which was formed only six years ago, has proved to be the strongest opposition party since independence; in a stunning challenge it won 57 of the directly contested seats in the 2000 election and might have done better had the electoral 'playing fields' been level (Saunders 2000; Commonwealth Observer Group 2000). Defining itself as a social democratic party, the MDC stated its aims, objectives and values as being to build 'an open democracy in which national government is accountable to the people through devolution of power and decision-making to the provinces, local institutions and structures' (MDC 1999). It added that it sought the mandate of the people 'to govern the country and work for a dynamic economy built on the principles of mixed economy with a strong social conscience'.

However, it should be stated that the past six years have witnessed a deep polarisation in Zimbabwean politics, including in inter-party politics. On the one hand there have been concerted efforts to 'de-legitimise' the MDC on a variety of grounds, including the allegation that it is 'a puppet' of the West, or, more specifically, of the Blair government. On the other hand, a plethora of legislation such as the Public Order and Security Act (POSA) has been brought into existence to restrict opposition party activities in the post-2000 election period. With the close contest in that election, prospects had improved for breaking the 'dominant party' straitjacket. However, what prevented this from happening was partly the maintenance of an anachronistic electoral system that gave a considerable advantage of an additional 30 seats to Zanu-PF. Had it not been for this, the MDC inroads would have paved the way for more robustly competitive two-party system (Sachikonye 2000; Masunungure 2004).

There were other players, although comparatively minor ones, in the 2005 election. They were Zanu-Ndonga, a small rump of the original Zanu, but relegated to the constituency of Chipinge in south-eastern Zimbabwe since independence. With the death of its autocratic aged leader, Ndabaningi Sithole, in 2000, the fortunes of the party faded considerably. The other contesting party, the Zimbabwe Youth Alliance (ZIYA), was formed only a few weeks before the election campaign began. ZIYA fielded four candidates and Zanu-Ndonga seven.

Finally, a significant number of candidates from both Zanu-PF and the MDCmost of whom had lost in party primary elections or had been blocked from standing in them - stood as independents. The electoral chances of independent candidates in Zimbabwe generally tend to be slim. The victory in Tsholotsho constituency in Matabeleland North of former Zanu-PF Cabinet Minister Jonathan Moyo, who had been expelled from the party, was the single exception.

\section{PARTY PRIMARIES}

The staging of primary elections by the main contesting parties was a key feature of the build-up to the campaign. Most of the primaries in Zanu-PF were organised in January 2005, and those in the MDC later in February. When primaries are 
properly held, they represent a barometer of the state of intra-party democracy. Some of the primary elections conducted in Zanu-PF turned out to be acrimonious. This was the case in the provinces of Manicaland, Masvingo, Matabeleland North and Matabeleland South. In Manicaland, the primaries were so acrimonious that the senior party stalwarts, Didymus Mutasa and Kumbirai Kangai, had to be exempted from the primary elections because of the sharp differences between the factions they headed. In December 2004, a team from the Zanu-PF head office was dispatched to Masvingo to resolve tensions between the provincial party leadership and the war veteran members while war veterans in the two Matabeleland provinces accused the party leadership of corrupt practices.

There was also much tension and jostling over the Tsholotsho seat where Moyo rejected the party recommendation that the seat be contested by a woman candidate to meet Zanu-PF's 30 per cent threshold for women. In some provinces, there were allegations of vote-buying by candidates during primaries, and in others there were charges that candidates were being imposed from the top. At the beginning of January, as the tension over the primaries reached fever pitch, President Mugabe had to intervene to cool tempers.

The MDC had its share of problems and tensions during the primaries. Intraparty squabbles marked the jockeying for candidature in such diverse constituencies as Masvingo Central, St Mary's in Chitungwiza and Mbare West in Harare. In Masvingo Central, there were clashes between supporters of the outgoing MP, Silas Mangono, and those of the incoming Tongai Mathuthu. There were press reports that the bodyguards of MDC President, Morgan Tsvangirai, had to intervene to defuse clashes between the two groups of supporters. In Mbare West, the incumbent MP, Danmore Makuwaza, who lost in the primary election, accused his opponent, MDC deputy Secretary General Gift Chimanikire, of abusing his position as one of the 'top six' leaders in the party in contesting the seat. Chimanikire was accused of having engaged in 'vote buying' during the primary election that he eventually won.

In sum, the primary elections were fiercely contested in both Zanu-PF and the MDC. However, both parties demonstrated limited experience and skills in the conduct of these elections. Allegations of the imposition of candidates from the top and of 'vote buying' were levelled within both parties. In addition, Zanu-PF's 30 per cent threshold for female candidates was a new dimension, added to accord with the SADC objective of increasing the proportion of women legislators by 2005 . Clearly, there remains a great deal of scope for improving the conduct and process of primary elections as an instrument of intra-party democracy.

\section{PARTY CAMPAignS}

The key campaign issues were the economic and political challenges facing Zimbabwe, and party manifestoes dealt with them at some length. For instance, Zanu-PF pledged to assert what it termed 'sovereignty over national resources', to 
stabilise the exchange rate and to raise Gross Domestic Profit (GDP) growth to between 3 and 5 per cent per annum. The party promised to adopt programmes that would increase investment, manufacturing and mining output while implementing a 'look East' policy to diversify markets. Other campaign pledges made by Zanu-PF were that it would construct 1,25-million houses by 2008 and revamp the health sector, together with increasing funding for an HIV-AIDS programme. AZanu-PF government would simultaneously refurbish the education infrastructure and expand university education. The land issue was prominent throughout the campaign, with Zanu-PF playing up its high-profile role in land redistribution while pledging to embark on comprehensive agricultural irrigation and mechanisation programme (Zanu-PF 2005). To that end, the government would provide finance and credit schemes to capitalise farmers' operations as well as long-term strategies to mitigate the effects of drought. Finally, the issue of leadership re-surfaced constantly during the campaign. Zanu-PF claimed that it offered voters its 'tried and tested leadership' for another five years in a direction that guaranteed that Zimbabwe would 'never be a colony again' (Zanu-PF 2005).

For its part, the MDC promised to build 'a new Zimbabwe' that would have 'freedom, prosperity, job opportunities, justice, safety and a living wage' (MDC 2005a). With respect to the economy, the party pledged to restore macro-economic stability, to reduce inflation to a single digit, to increase investment, especially in mining and manufacturing, while stabilising the foreign exchange market. Economic stability would be made possible partly by engaging the international community and negotiating loan rescheduling and debt relief. Furthermore, the party promised that, if elected to power, it would build 750000 houses within five years. The MDC would allocate 15 per cent of the budget to the health sector while, like Zanu-PF, substantially increasing funding to combat HIV-AIDS. The party would introduce 'free primary education for all' and protect 'the rights of private schools'. Finally, an MDC government would ensure 'recovery of the agricultural sector' and achieve food security within 100 days of coming to power. Through its land policy, the MDC would promote security of tenure by granting title to land users as well as providing inputs, extension and financial support for farmers.

Interestingly, there were more similarities than differences between these two major parties on socio-economic issues. Neither has broken out of the strait-jacket of neo-liberal macro-economic policies. The irreversibility of land reform and the priority of macro-economic stabilisation appeared to have been taken for granted by both parties. What was lacking was a more critical assessment of the consequences of Zanu-PF's land reform beyond redistribution. The MDC appeared not to have capitalised as much as it might have on the shortfalls of land reform. Its delay of four months in deciding whether or not to participate in the election affected the amount of time it could devote to its campaign in rural areas where land reform continues to be a priority issue but one that has also contributed to disgruntlement amongst some sections of rural voters. 
The ties the MDC continues to maintain with Western countries and donors made it vulnerable to Zanu-PF's nationalistic diatribes. The tag that it was a puppet of the Blair government was far fetched but it was a convenient 'smear tactic' that the MDC found irritating at each stage of the campaign. This 'demonisation' of the opposition was more a tactic of reverse 'demonisation' by Zanu-PF following criticism by the Western media than anything else. The same applied to the charge that the opposition was behind such sanctions as were currently being applied against Zimbabwe.

The Zanu-PF government was constantly attacked about restrictive laws that discriminated against the opposition and represented a breach of the SADC Principles and Guidelines. These laws, which included the Public Order and Security Act (POSA) of 2002, the Access to Information and Protection of Privacy Act (AIPPA) also of 2002 and the Citizenship of Zimbabwe Amendment Act of 2001, inhibited freedom of assembly, association and expression in the run-up to the election and affected the campaign environment negatively. They seriously disadvantaged the opposition, making the electoral field very uneven (ZLHR 2005). MDC rallies and meetings continued to be banned under POSA, while no ZanuPF rally was prohibited.

It is interesting to observe that there was scanty coverage of the campaigns of the independents. This stemmed from the fact that their decisions to stand independently often precipitated their marginalisation from the mainstream parties to which they had belonged. Independents often laboured under the disadvantages of limited campaign resources and a lack of visibility in the media. Local and constituency issues and priorities were their main focus but it was only in Tsholotsho that an independent candidate won, and even he owed a significant portion of his victory to the prior investment of largely state-derived resources in the constituency.

Finally, a major deficiency in the campaign was the absence of public debates between the leaders of the contesting political parties. No convincing reasons were presented by the public media, particularly television and radio, for not arranging debates between the leaders of the two major parties to give listeners and viewers the opportunity to make up their minds about the issues and personalities at stake.

\section{Use of State / Public Resources}

The distribution of state/public resources between contesting parties was skewed. The only mechanisms ensuring equitable access to state/public resources are contained in the provisions of the Political Parties Finance Act. Nevertheless, it is noteworthy that Zanu-PF and the MDC have been the principal beneficiaries of the Act, which uses the number of votes received by a party in a previous election as a formula for allocating funds. Based on their performance in the 2000 elections, some Z\$6,5-billion was shared between the two parties, with Zanu-PF receiving Z\$3,38-billion and the MDC Z\$3,12-billion. 
Unfortunately, the same formula was not replicated in the parties' access to the public media, campaign infrastructure, venues, transport and so on. Zanu-PF derived substantial advantages from incumbency. The party used state resources such as government transport while President Mugabe used Air Force helicopters and party officials used forms of transport such as District Development Fund (DDF - a government rural development fund) trucks to ferry ruling party supporters to campaign venues in Matabeleland South and Zupco buses and Department of Social Welfare trucks were allegedly used in the Chitungwiza campaign. In addition, there were instances in which it was unclear whether the agricultural inputs and maize meal distributed at rallies were the private property of the candidate or the party or came from public coffers.

It was commonplace for schools to be used as venues for Zanu-PF star rallies. A highlight of these rallies was the donation of computers to school heads for use by pupils. Although it was claimed that the computers were privately sourced with the assistance of the Reserve Bank governor, Gideon Gono, the timing of their allocation raised some questions. For example, it was estimated that schools in Mashonaland West received about 1000 computers from President Mugabe. In other instances, Zanu-PF candidates were seen giving out maize or making it available for sale at a reduced price during the campaign. Such was the case in Gutu in Masvingo and Dangamvura in Manicaland. The use of public resources as a form of patronage to sway voters is clearly an advantage that is not open to opposition parties, especially in rural areas.

The biggest debate, though, related to access to the public media, particularly during campaigns. It is a debate that goes back many years (ESC 1995; Sachikonye 2001 and EU 2000). The bulk of the news media in Zimbabwe are state-owned. Zimbabwe Broadcasting Holdings ( $\mathrm{ZBH}$ ) is currently the sole radio and television broadcaster, and state-controlled newspapers have a larger circulation than the few independently owned ones. As observed above, the public media have historically been partisan in their orientation and continue to be biased in favour of the ruling party. Although most (but not all) independent papers give considerable space to opposition views, they have relatively small circulations. There was no change in the patterns of this orientation and bias during the 2005 election campaign.

Although the SADC Principles and Guidelines stipulate that all parties should have equal access to the state media, neither the Zimbabwe Electoral Commission (ZEC) Act nor the Electoral Act contains provisions to ensure this. However, a new departure during the campaign was broadcasting regulations that facilitated access to the electronic media. A belated but welcome development in election broadcasting, the starting date of the broadcasts was 26 February 2005, a mere five weeks before the polling date. Parties were granted slots to present their manifestoes and programmes to the electorate on radio and television. Although parties were allowed to advertise on both media, it was prohibitively expensive to do so. For example, it cost $Z \$ 226-$ million for a party to secure an hour of prime time advertising on television and $\mathrm{Z} \$ 84-$ million on radio. Financial constraints, especially on 
opposition parties, subverted the theoretical entitlement to access to the electronic media. Finally, with respect to the print media, the ruling party profited from the unequivocal editorial support provided by the state-controlled dailies, the Herald and the Chronicle, and the Sunday papers, the Sunday Mail and the Sunday News. Some of the articles and profiles on opposition parties and leaders in the Herald and Sunday Mail were tantamount to brazen propaganda. With the closure in 2004 of the mass circulation Daily News, the MDC was at a great disadvantage.

\section{Controversy Over the Election Results}

Although the election campaign had largely been free from the political violence and intimidatory practices experienced in previous elections, the controversy over the outcome was similar to that which broke over the 2000 and 2002 results. The controversy was partly generated by lack of transparency at the counting and announcing of results. There were thus disputes between contesting parties over both process and outcome. Questions were raised about the location of some rural polling stations (ZESN 2005) some of which were located at the homesteads of chiefs who were reputed to be stalwart Zanu-PF supporters while others were next to police or army camps.

However, it was the opaque process of counting and the announcement of results that created doubts about the credibility of the election process. There were allegations that some election observers were 'unnecessarily detained' at polling stations after counting had been completed (ZESN 2005). In other instances, security personnel such as the police played an active role in the counting and transmission of results from the polling stations (US Embassy 2005). In terms of the Electoral Act, once counting had been completed at the polling station and the results conveyed to the constituency centre, the presiding officer of the polling station should display the results outside the station for the public to see. This was not done in some places and it was alleged that some chief election agents and candidates were prevented from communicating the results: 'many were locked in polling stations under police guard and denied permission to use cell phones' (MDC 2005b). There was also a specific allegation that opposition party officials and candidates were forced to leave command centres when tallies came in from polling stations. It was suggested that if the ZEC had provided observers with unfettered access to vote counting at polling stations they would have been in a position to verify the results and help resolve election-related disputes (ZESN 2005).

More serious were the discrepancies between the number of cast votes the ZEC announced on the night of 31 March and the morning of 1 April and the final results, announced later. Two examples of such discrepancies, which reportedly occurred in about 30 constituencies, concerned the votes in Goromonzi and Manyame constituencies. In Goromonzi, a constituency won by Zanu-PF, the number of votes announced by the ZEC at 2am on 1 April 2005 had suddenly gone up by 62 per cent from 15611 to 25360 by the time the final results were announced. 
Another example pertains to Manyame constituency, also won by Zanu-PF. According to the ZEC, 14812 voters had cast their ballots when the polls closed - a figure that had catapulted by 72 per cent to 23760 when the final result was announced. Significantly, most of the discrepancies were in rural constituencies which were won by Zanu-PF candidates. It was charged that 'where the MDC was widely predicted to regain seats, such as in Harare and Bulawayo, very few discrepancies were identified. This raises further suspicions that there was a calculated plan to ensure that the MDC won a "sufficient" number of seats to provide the electoral process with a veneer of legitimacy' (MDC 2005b).

It is also politically significant that it was several days before the ZEC formally responded to the charges of vote discrepancies. Some six days after the charges were first made by opposition parties, NGOs and some observers, the ZEC chairperson told a press conference that the figures announced in the updates of 31 March were not necessarily an accurate reflection of the facts (Justice Chiweshe, quoted in the Zimbabwe Independent 8 April 2005). He contended that the figures had been intended to give an indication of the turnout trends in various provinces and constituencies. Whatever the truth of the matter, the clumsiness and opaqueness of the ZEC in handling this matter damaged the credibility of the results.

\section{CONCLUSION}

Although the 2005 election represented an improvement in terms of a peaceful atmosphere, the structural issues of unequal access to resources and authoritarian restrictive laws marred the democratic framework of the contest. The difficulty of attaining a high standard of transparency and credibility in the election process reflected concerns that 'there is still inadequate and lip service commitment to multiparty democracy and politics among some of our leaders and politicians. They talk of democracy but use undemocratic means to gain or remain in power. Yet the success of multi-party democracy and politics depends to a large extent on government, political parties and other stakeholders committing themselves to upholding the values and practices that go with these concepts ...' (SADC Parliamentary Forum 2001). The 2005 elections revealed the deficit in Zimbabwe's democratisation process. Although there was a semblance of competition in the contest, structural impediments remained. The raft of laws restricting political activities and media freedom should be repealed.

The current structural framework has frustrated the appearance of a more competitive party system, especially since 2000. The implicit agenda of Zanu-PF appears to be to sustain and reproduce a 'dominant-party' system, particularly one underwritten by a two-thirds majority in Parliament. Thus there has been a conscious attempt to turn the political clock back to the period before 2000, a factor that has undermined the prospects of democratisation. The 'dominant-party' syndrome is commonly associated with phenomena such as the fusion of party and state, the denunciation of minorities who mobilise on issues vital to them, and 
the de-legitimisation of the opposition (Southall 2003). The growth among powerholders of 'a culture of entitlement' to state resources, and even to resources not owned by the state, is an accompaniment to and consequence of this syndrome.

Although the specific disputed results will be brought before the Electoral Court and, indeed, other courts of law, a cloud has hung over the outcome of the 2005 elections. Instead of lifting the pall of uncertainty over the country, this has cast gloom, at least in the short and medium term. The need for deep political, constitutional and electoral reforms has never been more imperative.

\section{- REFERENCES ——}

Commonwealth Observer Group. 2000. The Parliamentary Elections in Zimbabwe: Report of the Commonwealth Observer Group. London.

-2002. The Zimbabwe Presidential Election, March 2002: Report of the Commonwealth Observer Group. London.

Electoral Supervisory Commission(ESC). 1995. Report of the Electoral Supervisory Commission on the General Elections. Harare: ESC.

European Union(EU). 2000. Report on the Parliamentary Elections in Zimbabwe, 2000 Brussels: EU Observation Mission.

Hall, JA.1992.'Consolidations of Democracy'.InD Held (ed) Prospects for Democracy. London: Polity Press.

Movement for Democratic Change (MDC). 1999. Constitution. Harare: MDC

-2005a. Manifesto. Harare: MDC. .2005b. Stolen: the will of the people denied again. Harare: MDC

Mainwaring, S. 1998. 'Party Systems in the Third Wave' Journal of Democracy 9(3).

Masunungure, E. 2004. 'Travails of Opposition Politics in Zimbabwe since Independence'. In D Harold-Barry (ed) Zimbabwe: the Past is the Future. Harare: Weaver Press.

Sachikonye, L M. 2000. 'Just a Victory'. Sapem, July.

.2001. 'An Audit of the Zimbabwe Electoral System'. In H Kotze and B Raach (eds) Elections and Democracy in Southern Africa. Oslo: NIHR.

SADC. 2004. SADC Principles and Guidelines Governing Democratic Elections. Port Louis: SADC. SADC Parliamentary Forum. 2001. Norms and Standards for Elections in the SADC Region. Gaborone.

Saunders, D. 2000. Never the Same Again. Harare: Saunders.

Southall, R. 2003. 'Democracy in Southern Africa: moving beyond a difficult legacy'. Review of African Political Economy 30(96).

US Embassy. 2005. 'Report on the 2005 Elections'. Harare: Unpublished mimeo.

Zanu-PF. 1999. Constitution. Harare: Zanu-PF.

.2005. Manifesto. Harare: Zanu-PF.

Zimbabwe Election Support Network (ZESN). 2005. Report on the 2005 Election. Harare: ZESN

Zimbabwe Lawyers for Human Rights (ZLHR). 2005. The Pre-Election Environment in Zimbabwe. Harare. 